\title{
PERHITUNGAN NILAI BETA DARI BEBERAPA SAHAM UNGGULAN DI INDONESIA DENGAN MENGGUNAKAN METODE GARCH
}

\author{
Ni Kadek Puspitayanti ${ }^{\S 1}$, Komang Dharmawan ${ }^{2}$, I Putu Eka N. Kencana ${ }^{3}$ \\ ${ }^{1}$ Jurusan Matematika, Fakultas MIPA - Universitas Udayana [Email: adex_math05@yahoo.com] \\ ${ }^{2}$ Jurusan Matematika, Fakultas MIPA - Universitas Udayana [Email: dharmawan.komang@gmail.com] \\ ${ }^{3}$ Jurusan Matematika, Fakultas MIPA - Universitas Udayana [Email: i.putu.enk@gmail.com] \\ ${ }^{\S}$ Corresponding Author
}

\begin{abstract}
The objective of investment in the capital market is to acquire dividends and capital gain. The fact proves that the advantage of investation risky assets is uncertain. This is because of the difficulty in analyzing and predicting Return and stock losses due to factors that affect the movement of the stock price, such as economic factors, political, social, and security. The model can be used by investors in predicting stock returns expected that Generalized Autoregressive Conditional Heteroscedaticity (GARCH). In this study calculations beta value of some leading stocks in Indonesia by using Generalized Autoregressive Conditional Heteroscedaticity (GARCH) are presented. The data used this search is secondary data covering daily data sampled 5 shares of PT Unilever Indonesia Tbk, PT Indosat Tbk, PT Indofood Sukses Makmur Tbk, PT Telkom Indonesia Tbk, PT Holcim Indonesia Tbk. From the results described fifth beta value of these shares using the method GARCH beta greater than the market in the period from 23 September 2013 until 24 September 2014.
\end{abstract}

Keywords: Beta, Capital Gain, Dividen, GARCH, return

\section{PENDAHULUAN}

Investasi dibedakan menjadi dua yaitu investasi riil (gedung, kendaraan, mesin, tanah) dan investasi finansial (saham pada pasar modal). Tingkat pendapatan yang diharapkan dari investasi saham tergantung dari bagaimana sikap investor dalam menghadapi risiko. Pada umumnya investor bersifat menghindari risiko, walaupun sebagian ada yang berani mengambil risiko. Investor akan mempertimbangkan tingkat penghasilan yang diharapkan (expeted return) atas investasinya untuk periode tertentu pada masa yang akan datang terhadap risiko (risk) yang akan mungkin ditanggung.

Pasar modal menyediakan banyak sekali informasi yang tersedia bagi para investor. Informasi merupakan kebutuhan yang mendasar bagi para investor dalam mengambil keputusan. Seorang investor harus memiliki perencanaan investasi yang efektif agar memperoleh keuntungan di pasar modal. Perencanaan ini meliputi pertimbangan keputusan yang diambil untuk mengalokasikan dana yang dimiliki dalam bentuk aktiva tertentu dengan harapan mendapat keuntungan ekonomis di masa mendatang. Salah satu bentuk investasi yang dilakukan investor adalah membeli saham, dengan harapan akan memperoleh return baik berupa dividen maupun capital gain.

Dalam pelaksanaan investasi, para pemilik modal (investor) sangat membutuhkan informasi yang jelas, wajar, dan tepat waktu sebagai dasar pertimbangan dalam proses pengambilan keputusan. Salah satu informasi yang dibutuhkan oleh investor (baik investor ritel maupun investor institusional) adalah informasi tentang tingkat pengembalian (return) dan risiko investasi. Metode yang digunakan untuk mengestimasi beta dengan varians adalah metode Generalized Autoregressive Conditional Heteroscedaticity (GARCH). Nilai beta yang telah diperoleh dengan metode GARCH dapat digunakan untuk estimasi sensivitas pengembalian saham beta yang akan 
datang sehingga dapat digunakan oleh investor sebagai bahan pertimbangan untuk membuat keputusan investasi.

\section{METODE PENELITIAN}

Data yang digunakan dalam penelitian ini adalah data sekunder yang bersifat kuantitatif. Data sekunder adalah data yang diambil tidak dari sumber langsung dan merupakan pengumpulan dari pihak lain. Sedangkan data yang bersifat kuantitatif adalah data yang berupa angka yang bisa dihitung atau dioperasikan. Data dalam penelitian ini diakses melalui internet.

\section{A. Mencari Tingkat Pengembalian (Return)}

Return saham adalah keuntungan yang di peroleh dari kepemilikan saham investasi yang dilakukan. Perhitungan return saham menggunakan metode konvensional sebagai berikut:

$$
R_{i, t}=\frac{S_{i, t}-S_{i, t-1}}{S_{i, t-1}}
$$

dengan $R_{i, t}$ adalah return saham $i$ pada periode $t, S_{i, t}$ adalah indeks saham $i$ pada periode $t$, dan $S_{i, t-1}$ adalah indeks saham $i$ pada periode $t-$ 1.

Pada analisis sekuritas umumnya menggunakan metode natural logarithm ratio, dimana hasil dari keuntungan yang diharapkan tidak terlalu besar dibandingkan metode konvensional. Metode natural logarithm ratio di formulasikan sebagai (Husnan [5])

$$
R_{i, t}=\ln \left(\frac{s_{i, t}}{s_{i, t-1}}\right)
$$

Penggunaan metode natural logarithm ratio digunakan agar dalam analisis statistika perhitungan return tidak bisa.

\section{B. Fungsi ACF dan PACF}

Fungsi autokorelasi digunakan untuk meng ukur ketergantungan bersama (mutual dependen) antara nilai-nilai suatu runtun waktu yang sama pada periode waktu yang berlainan.

$$
\rho_{k}=\frac{\sum_{t=1}^{n-k}\left(Z_{t}-\bar{Z}\right)\left(Z_{t+k}-\bar{Z}\right)}{\sum_{t=1}^{n}\left(Z_{t}-\bar{Z}\right)^{2}}
$$

dengan nilai $\rho_{k}$ berkisar antara -1 sampai 1 . Untuk fungsi PACF diberikan sebagai berikut

$$
=\frac{\rho_{k}-\sum_{j=1}^{k-1} \widehat{\emptyset}_{k-1, j} \rho_{k-j}}{1-\sum_{j=1}^{k-1} \widehat{\emptyset}_{k-1, j} \rho_{j}}
$$

dengan $\widehat{\emptyset}_{k j}=\widehat{\emptyset}_{k-1, j}-\emptyset_{k k} \widehat{\emptyset}_{k-1, k-j} \quad$ untuk $j=1,2,3, \ldots, k-1$.

C. Uji Ljung Box

Pada Uji Ljung Box akan dilakukan pengujian terhadap data apakah mempunyai unsur autokorelasi atau tidak.

a. Menetapkan hipotesis

$H_{0}$ : data tidak berautokorelasi

$H_{1}$ : data memiliki autokorelasi

b. Menghitung uji statistik Ljung-Box

$$
L B=n(n+2) \sum_{k=1}^{m}\left(\frac{\hat{\rho}_{k}^{2}}{n-k}\right)
$$

dengan LB menyatakan statistik Ljung Box, $n$ menyatakan banyaknya data pengamatan, $\hat{\rho}_{k}^{2}$ merupakan taksiran autokorelasi, dan $m$ adalah panjang lag.

c. Daerah penolakan

Kriteria uji dilakukan jika $H_{0}$ ditolak jika LB $>x_{a ; d f}^{2}$ atau p-value $<0$. Apabila $H_{0}$ ditolak maka akan dipilih $H_{1}$ yang berarti data berautokorelasi.

\section{Uji ARCH LM}

Uji ARCH LM dilakukan untuk melihat kehadiran unsur heteroscedasticity atau efek GARCH.

a. Menetapkan hipotesis

$H_{0}$ : homoscedasticity, tidak ada efek ARCH-GARCH

$H_{1}$ : heteroscedasticity, terdapat efek ARCH-GARCH

b. Menghitung nilai statistik uji $\mathrm{ARCH}$ LM

$$
U=(n-m) R^{2}
$$


$R^{2}$ merupakan koefisien determinasi, $n$ banyaknya data dan $m$ panjang lag.

c. Daerah penolakan

Kriteria uji dilakukan apabila tolak $H_{0}$ jika $U>x_{a, m}^{2}$ atau $p$-value $<\alpha$, maka akan dipilih $H_{1}$ yang berarti ada efek ARCH-GARCH pada data

\section{E. Peramalan dengan model Generalized Autoregressive Conditional Heteroskedasticity (GARCH)}

Model ARCH pada umumnya digunakan untuk memperkirakan volatilitas yang diperkenalkan oleh Engle pada tahun 1982 di mana $\varepsilon_{t}$ tidak saling berkorelasi. Residual $\left(\varepsilon_{t}\right)$ mengikuti model ARCH $(q)$ yang dimodelkan sebagai

$$
\begin{gathered}
\varepsilon_{t}=\sigma_{t} Z_{t} \\
\sigma_{t}^{2}=\omega+\beta_{1} \varepsilon_{t-1}^{2}+\cdots+\beta_{q} \varepsilon_{t-q}^{2} \\
\sigma_{t}^{2}=\omega+\sum_{i=1}^{q} \beta_{i} \varepsilon_{t-i}^{2}
\end{gathered}
$$

dengan $\beta_{1}, \ldots, \beta_{i}$, dan $\omega$ merupakan parameter konstan. Bollerslev mengembangkan model ARCH menjadi model GARCH di mana residual $\left(\varepsilon_{t}\right)$ mengikuti model GARCH $(p, q)$ dengan $q$ merupakan orde $\mathrm{ARCH}$ dan $p$ merupakan orde dari GARCH yang dapat dimodelkan sebagai

$$
\begin{gathered}
\varepsilon_{t}=\sigma_{t} Z_{t} \\
\sigma_{t}^{2}=\omega+\alpha_{1} \sigma_{t-1}^{2}+\cdots+\alpha_{p} \sigma_{t-p}^{2}+\beta_{1} \varepsilon_{t-1}^{2}+\cdots \\
+\beta_{q} \varepsilon_{t-q}^{2}
\end{gathered}
$$

Untuk GARCH $(p, q)$ variansnya dapat dirumuskan sebagai berikut:

$$
\sigma_{t}^{2}=\omega+\sum_{j=1}^{p} \alpha_{j} \sigma_{t-j}^{2}+\sum_{i=1}^{q} \beta_{i} \varepsilon_{t-i}^{2}
$$

dengan $\alpha_{1}, \alpha_{2}, \ldots, \alpha_{j}$ adalah nilai parameter ke $i$ dari GARCH dan $\sigma_{t-1}^{2}, \sigma_{t-2}^{2}, \ldots, \sigma_{t-i}^{2}$ adalah nilai varians ke $t$.

\section{F. Perhitungan Nilai Beta Saham Unggulan}

Menghitung Nilai Beta tiap-tiap saham menggunakan GARCH. Beta merupakan ukuran sensitivitas pengembalian saham terhadap perubahan pengembalian pasar. Perhitungan beta sangat penting dilakukan untuk mengetahui berapa besar risiko saham tersebut. Saham dengan nilai $\beta>1$ memiliki risiko lebih tinggi dari risiko pasar, sebaliknya saham dengan nilai $\beta<1$ memiliki risiko lebih rendah dari risiko pasardan sedangkan saham dengan nilai $\beta=1$ menunjukkan bahwa risiko saham sama dengan risiko pasar. Risiko sistematis merupakan risiko yang berasal dari kondisi ekonomi dan kondisi pasar secara umum, dimana risiko ini tercermin dari nilai betanya.

\section{G. Perbandingan Nilai Beta saham Unggulan.}

Melakukan perbandingan nilai beta pasar saham unggulan.

\section{HASIL PENELITIAN DAN DISKUSI}

\section{A. Tingkat Pengembalian (Return)}

Menentukan nilai return dari data historis penutupan tiap-tiap saham dengan menggunakan metode Metode natural logarithm ratio di formulasikan sebagai (Husnan [5]).

$$
R_{i, t}=\ln \left(\frac{S_{i, t}}{S_{i, t-1}}\right)
$$

Berikut adalah plot data return tiap-tiap saham
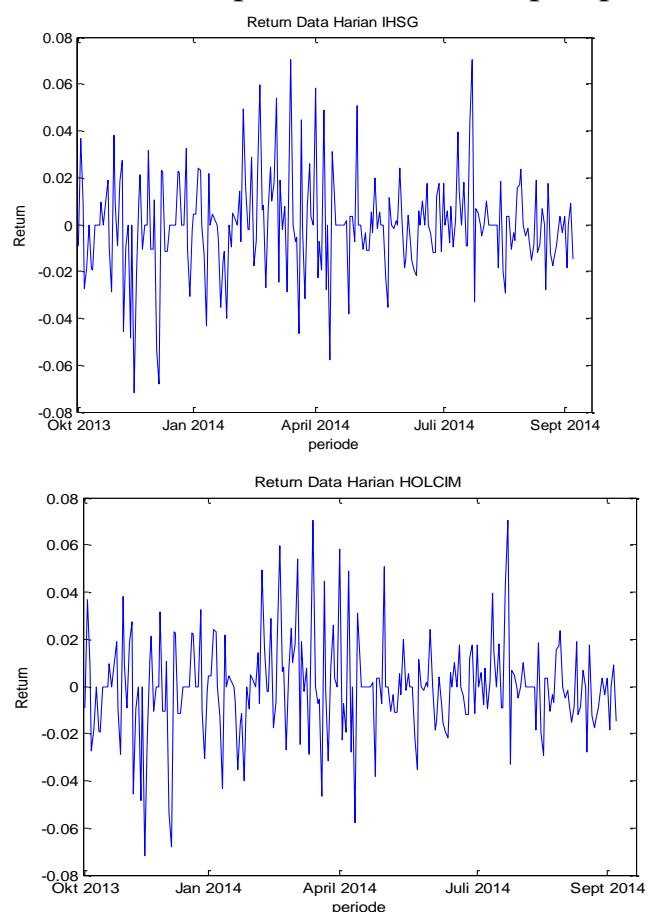

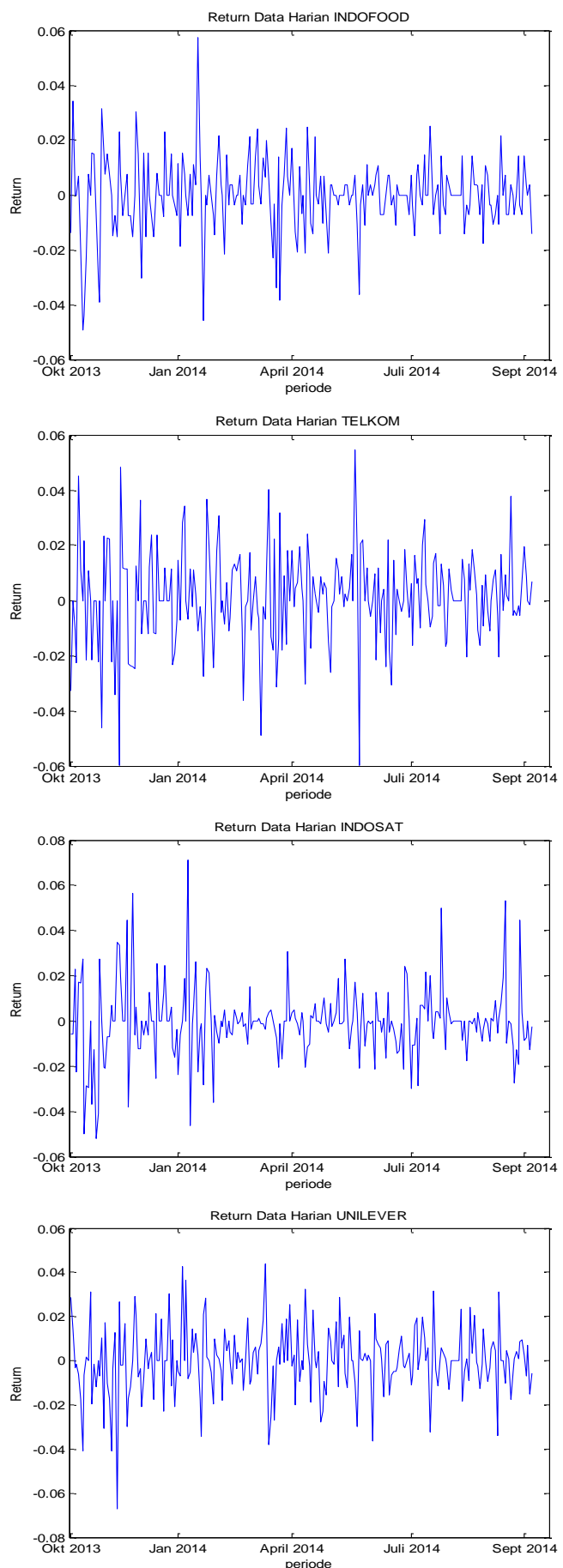

B. Generalized Autoregressive Conditional Heteroskedasticity (GARCH)

Penggunaan model GARCH yang digunakan dalam meramalkan model data yang bersifat acak dan volatilitasnya tidak konstan perlu memerhatikan langkah-langkah sebagai berikut, yaitu tahap pra-estimasi dengan melakukan uji terhadap autokorelasi data. Dengan melihat residual kuadratpada data akan dilihat bahwa data berautokorelasi atau tidak stasioner pada Tabel 3.1

\begin{tabular}{|c|c|c|c|c|c|}
\hline \multicolumn{6}{|c|}{ Saham IHSG } \\
\hline \multicolumn{3}{|c|}{$\begin{array}{c}\text { Uji Ljung Box Residual } \\
\text { Kuadrat }\end{array}$} & \multicolumn{3}{|c|}{$\begin{array}{c}\text { UJI ARCH Residual } \\
\text { Kuadrat }\end{array}$} \\
\hline $\mathbf{p}$ & Qstat & CV & $\mathbf{p}$ & Qstat & CV \\
\hline 0.8902 & 0.0191 & 3.8415 & 0.8893 & 0.0194 & 3.8415 \\
\hline 0.4882 & 4.4382 & 11.0705 & 0.6545 & 3.2959 & 11.0705 \\
\hline 0.5478 & 7.8649 & 16.9190 & 0.5554 & 7.7908 & 16.9190 \\
\hline 0.6150 & 10.9504 & 22.3620 & 0.6177 & 10.9175 & 22.3620 \\
\hline 0.4553 & 16.9866 & 27.5871 & 0.3708 & 18.2900 & 27.5871 \\
\hline 0.2917 & 24.0278 & 32.6706 & 0.4755 & 20.7301 & 32.6706 \\
\hline \multicolumn{6}{|c|}{ Holcim } \\
\hline $\mathbf{p}$ & Qstat & $\mathrm{CV}$ & $\mathbf{p}$ & Qstat & $\mathrm{CV}$ \\
\hline 0.1474 & 2.0987 & 3.8415 & 0.1506 & 2.0660 & 3.8415 \\
\hline 0.6533 & 3.3035 & 11.0705 & 0.6461 & 3.3509 & 11.0705 \\
\hline 0.2409 & 11.5335 & 16.9190 & 0.1794 & 12.6440 & 16.9190 \\
\hline 0.0489 & 22.4399 & 22.3620 & 0.1303 & 18.7741 & 22.3620 \\
\hline 0.0270 & 29.9122 & 27.5871 & 0.1141 & 24.2014 & 27.5871 \\
\hline 0.0249 & 35.4959 & 32.6706 & 0.1949 & 26.3086 & 32.6706 \\
\hline \multicolumn{6}{|c|}{ Indofood } \\
\hline $\mathbf{p}$ & Qstat & CV & $\mathbf{p}$ & Qstat & CV \\
\hline 0.0042 & 8.2058 & 3.8415 & 0.0045 & 8.0710 & 3.8415 \\
\hline 0.0036 & 17.5508 & 11.0705 & 0.0014 & 19.7588 & 11.0705 \\
\hline 0.0005 & 29.6503 & 16.9190 & 0.0007 & 28.7490 & 16.9190 \\
\hline 0.0025 & 31.9264 & 22.3620 & 0.0000 & 43.4200 & 22.3620 \\
\hline 0.0129 & 32.5277 & 27.5871 & 0.0159 & 31.8022 & 27.5871 \\
\hline 0.0443 & 33.1801 & 32.6706 & 0.0267 & 35.2250 & 32.6706 \\
\hline \multicolumn{6}{|c|}{ Indosat } \\
\hline p & Qstat & CV & p & Qstat & CV \\
\hline 0.0029 & 8.8761 & 3.8415 & 0.0031 & 8.7417 & 3.8415 \\
\hline 0.0050 & 16.7279 & 11.0705 & 0.0349 & 11.9923 & 11.0705 \\
\hline 0.0056 & 23.2624 & 16.9190 & 0.0794 & 15.4465 & 16.9190 \\
\hline 0.0178 & 25.8593 & 22.3620 & 0.2293 & 16.3781 & 22.3620 \\
\hline 0.0175 & 31.4599 & 27.5871 & 0.3581 & 18.4982 & 27.5871 \\
\hline 0.0314 & 34.5793 & 32.6706 & 0.4690 & 20.8368 & 32.6706 \\
\hline \multicolumn{6}{|c|}{ Unilever } \\
\hline $\mathbf{p}$ & Qstat & $\mathrm{CV}$ & $\mathbf{p}$ & Qstat & CV \\
\hline 0.3604 & 0.8363 & 3.8415 & 0.3624 & 0.8296 & 3.8415 \\
\hline 0.5933 & 3.7004 & 11.0705 & 0.6282 & 3.4682 & 11.0705 \\
\hline 0.8039 & 5.3380 & 16.9190 & 0.6991 & 6.4020 & 16.9190 \\
\hline 0.9509 & 5.8658 & 22.3620 & 0.9078 & 6.8877 & 22.3620 \\
\hline 0.9684 & 7.9103 & 27.5871 & 0.9370 & 9.1022 & 27.5871 \\
\hline 0.9579 & 11.2400 & 32.6706 & 0.9097 & 12.9704 & 32.6706 \\
\hline \multicolumn{6}{|c|}{ Telkom } \\
\hline $\mathbf{p}$ & Qstat & $\mathrm{CV}$ & $\mathbf{p}$ & Qstat & $\mathrm{CV}$ \\
\hline 0.1801 & 1.7965 & 3.8415 & 0.1811 & 1.7883 & 3.8415 \\
\hline 0.0933 & 9.4230 & 11.0705 & 0.1224 & 8.6826 & 11.0705 \\
\hline 0.1932 & 12.3718 & 16.9190 & 0.1391 & 13.5552 & 16.9190 \\
\hline 0.4219 & 13.3404 & 22.3620 & 0.2821 & 15.4161 & 22.3620 \\
\hline 0.4126 & 17.6286 & 27.5871 & 0.2041 & 21.5155 & 27.5871 \\
\hline 0.5590 & 19.4072 & 32.6706 & 0.2649 & 24.5991 & 32.6706 \\
\hline
\end{tabular}

Dari Tabel 3.1 dapat dilihat bahwa berdasarkan Uji Ljung-box residual kuadrat dan uji ARCH LM terhadap nilai dugaan residual kuadratnya diperoleh bahwa nilai Q lebih besar dari Critical Value (CV) atau nilai P lebih kecil dari $a=0,05$ yang mengindikasikan tolak $H_{0}$ atau terima $H_{1}$ yang artinya nilai dugaan residual kuadrat IHSG berautokorelasi atau 
tidak stasioner dan terdapat efek ARCHGARCH pada data return IHSG sehingga memungkinkan peramalan menggunakan model GARCH. Penentuan model GARCH dapat dilihat dari plot ACF dan PACF residual kuadrat pada Gambar berikut
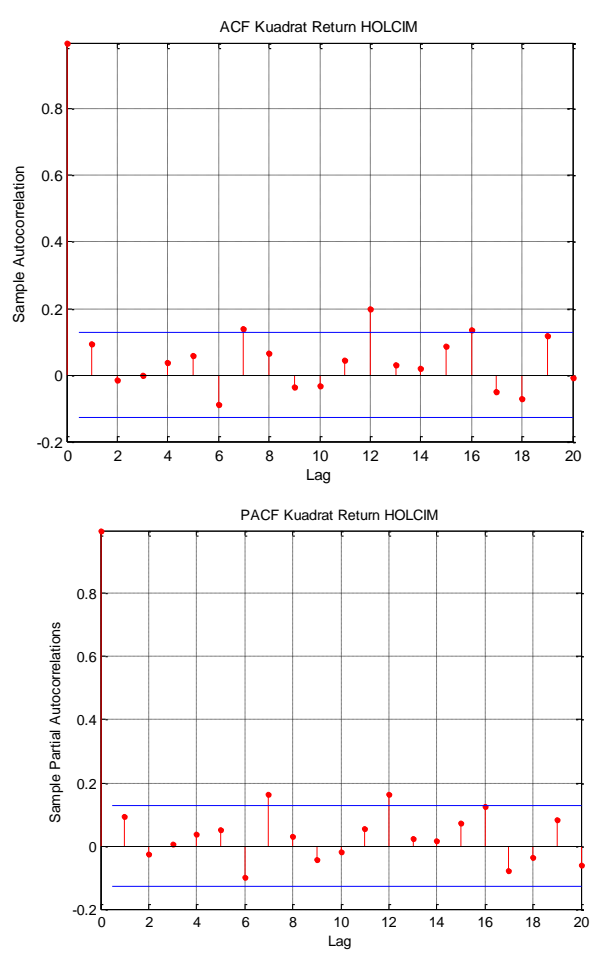

Peramalan dengan model GARCH akan dilakukan dengan mengestimasi parameterparameter model GARCH untuk memperoleh model GARCH yang terbaik. Beberapa model GARCH yang dapat dibentuk berdasarkan plot ACF dan PACF residual kuadrat IHSG dapat dilihat pada Tabel 3.2

Tabel 3.2. Model GARCH

\begin{tabular}{|c|c|c|c|c|}
\hline Model & $\begin{array}{c}\text { GARCH } \\
(1,1)\end{array}$ & $\begin{array}{c}\text { GARCH } \\
(1,2)\end{array}$ & $\begin{array}{c}\text { GARCH } \\
(2,1)\end{array}$ & $\begin{array}{c}\text { GARCH } \\
(2,2)\end{array}$ \\
\hline $\mathrm{K}$ & $2 \mathrm{e}-007$ & $2 \mathrm{e}-007$ & $2 \mathrm{e}-007$ & $2 \mathrm{e}-007$ \\
& {$[0.1055]$} & {$[0.1083]$} & {$[0.1040]$} & {$[0.0620]$} \\
\hline$G_{1}$ & 0,9708 & 0.96969 & 0.97033 & 0.081502 \\
& {$[27,5780]^{*}$} & {$[28.3250]^{*}$} & {$[0.3450]$} & {$[0.5776]$} \\
\hline$G_{2}$ & & & 0.00048781 & 0.86447 \\
& & & {$[0.0002]$} & {$[5.7269]$} \\
\hline$A_{1}$ & 0,023387 & & 0.023371 & \\
& {$[1.3407]$} & & {$[0.3581]$} & \\
\hline$A_{2}$ & & 0.024336 & & \\
& & {$[0.3641]$} & & \\
\hline AIC & -1.5792 & -1.5776 & -1.5772 & -1.5772 \\
\hline BIC & -1.5654 & -1.5603 & -1.5599 & 1.5564 \\
\hline
\end{tabular}

diketahui hasil estimasi koefisien model GARCH IHSG, dimana peramalan menggunakan model GARCH $(1,1)$ paling baik dibanding model GARCH yang lainnya. Hal ini dapat dilihat dari uji AIC dan BIC yang memberikan nilai minimum pada peramalan model GARCH $(1,1)$. Sehingga model GARCH $(1,1)$ pada IHSG adalah

$$
\begin{aligned}
\sigma_{t}^{2}=0,0000002 & +0,9708 \sigma_{t-1}^{2} \\
& +0,023387 \varepsilon_{t-1}^{2}
\end{aligned}
$$

dengan $\sigma_{t}^{2}$ adalah ramalan nilai variansi periode $t, \varepsilon_{t-1}^{2}$ adalah nilai residual periode $t-1$, dan $\sigma_{t-1}^{2}$ adalah nilai variansi periode $t-1$.

Tabel 3.3. Estimasi Parameter Model GARCH pada Holcim

\begin{tabular}{|c|c|c|c|c|}
\hline Model & $\begin{array}{c}\text { GARCH } \\
(1,1)\end{array}$ & $\begin{array}{c}\text { GARCH } \\
(1,2)\end{array}$ & $\begin{array}{c}\text { GARCH } \\
(2,1)\end{array}$ & $\begin{array}{c}\text { GARCH } \\
(2,2)\end{array}$ \\
\hline $\mathrm{K}$ & $1.7014 \mathrm{e}-$ & $1.6979 \mathrm{e}-$ & $2.5803 \mathrm{e}-$ & $2.58 \mathrm{e}-$ \\
& 005 & 005 & 005 & 005 \\
& {$[1.5564]$} & {$[1.2872]$} & {$[1.4442]$} & {$[1.3279]$} \\
\hline$G_{1}$ & 0.89166 & 0.89176 & 0.084879 & 0.084899 \\
& {$[22.8302]^{*}$} & {$[17.2216]^{*}$} & {$[0.7989]$} & {$[0.6078]$} \\
\hline$G_{2}$ & & & 0.74043 & 0.74041 \\
& & & {$[6.4438]^{*}$} & {$[5.9838]^{*}$} \\
\hline$A_{1}$ & 0.069975 & 0.069968 & 0.11548 & 0.11548 \\
& {$[2.6688]^{*}$} & {$[1.8117]^{*}$} & {$[3.0235]^{*}$} & {$[2.8273]^{*}$} \\
\hline$A_{2}$ & & & & \\
\hline AIC & -1.1838 & -1.1818 & -1.1842 & -1.1822 \\
\hline BIC & -1.1700 & -1.1645 & -1.1669 & -1.1615 \\
\hline
\end{tabular}

Keterangan: tanda $[\ldots]^{*}$ menunjukkan T-Stat $>$ T-tab pada $\alpha=0,05$

Berdasarkan Tabel 3.3 diketahui hasil estimasi koefisien model GARCH IHSG, dimana peramalan menggunakan model GARCH $(1,1)$ paling baik dibanding model GARCH yang lainnya. Hal ini dapat dilihat dari uji AIC dan BIC yang memberikan nilai minimum pada peramalan model GARCH $(1,1)$. Sehingga model GARCH $(1,1)$ pada Holcim adalah $\sigma_{t}^{2}=0,0017014+0.89166 \sigma_{t-1}^{2}+0.069975 \varepsilon_{t-1}^{2}$ dengan $\sigma_{t}^{2}$ adalah ramalan nilai variansi periode $t, \varepsilon_{t-1}^{2}$ adalah nilai residual periode $t-1$, dan $\sigma_{t-1}^{2}$ adalah nilai variansi periode $t-1$.

Tabel 3.4 menunjukkan hasil estimasi koefisien model GARCH IHSG, dimana peramalan menggunakan model GARCH $(1,1)$ paling baik dibanding model GARCH yang lainnya. Hal ini dapat dilihat dari uji AIC dan BIC yang memberikan nilai minimum pada peramalan model GARCH $(1,1)$. Sehingga model GARCH $(1,1)$ pada Indofood adalah 


$$
\begin{aligned}
\sigma_{t}^{2}=0,0019365 & +0.76183 \sigma_{t-1}^{2} \\
& +0.1268 \varepsilon_{t-1}^{2}
\end{aligned}
$$

dengan $\sigma_{t}^{2}$ adalah ramalan nilai variansi periode $t, \varepsilon_{t-1}^{2}$ adalah nilai residual periode $t-1$, dan $\sigma_{t-1}^{2}$ adalah nilai variansi periode $t-1$.

Tabel 3.4. Estimasi Parameter Model GARCH pada Indofood

\begin{tabular}{|c|c|c|c|c|}
\hline Model & $\begin{array}{c}\text { GARCH } \\
(1,1)\end{array}$ & $\begin{array}{c}\text { GARCH } \\
(1,2)\end{array}$ & $\begin{array}{c}\text { GARCH } \\
(2,1)\end{array}$ & $\begin{array}{c}\text { GARCH } \\
(2,2)\end{array}$ \\
\hline $\mathrm{K}$ & $\begin{array}{c}1.9365 \mathrm{e}- \\
005 \\
{[1.8892]^{*}}\end{array}$ & $\begin{array}{c}1.9376 \mathrm{e}- \\
005 \\
{[1.6658]^{*}}\end{array}$ & $\begin{array}{c}5.5137 \mathrm{e}- \\
007 \\
{[0.3238]}\end{array}$ & $\begin{array}{c}5.4817 \mathrm{e}- \\
007 \\
{[0.3016]}\end{array}$ \\
\hline$G_{1}$ & 0.76183 & 0.76187 & & \\
\hline$G_{2}$ & & & 0.93618 & 0.93622 \\
& & & {$[6.3123]^{*}$} & \\
\hline$A_{1}$ & 0.1268 & 0.1267 & 0.051026 & 0.051015 \\
& {$[2.2788]^{*}$} & {$[1.8563]^{*}$} & {$[2.7831]^{*}$} & {$[2.6557]^{*}$} \\
\hline$A_{2}$ & & & & \\
\hline AIC & -1.4122 & -1.4102 & -1.4202 & -1.4182 \\
\hline BIC & -1.3984 & -1.3929 & -1.4029 & -1.3975 \\
\hline
\end{tabular}

Keterangan: tanda $[\ldots]^{*}$ menunjukkan T-Stat $>$ T-tab pada $\alpha=0,05$

Tabel 3.5 Estimasi Parameter Model GARCH

\begin{tabular}{|c|c|c|c|c|}
\hline Model & $\begin{array}{c}\text { GARCH } \\
(1,1)\end{array}$ & $\begin{array}{c}\text { GARCH } \\
(1,2)\end{array}$ & $\begin{array}{c}\text { GARCH } \\
(2,1)\end{array}$ & $\begin{array}{c}\text { GARCH } \\
(2,2)\end{array}$ \\
\hline K & $\begin{array}{c}1.7467 \mathrm{e}- \\
005 \\
{[3.1300]^{*}}\end{array}$ & $\begin{array}{c}1.7527 \mathrm{e}- \\
005 \\
{[2.4390]^{*}}\end{array}$ & $\begin{array}{c}1.745 \mathrm{e}- \\
005 \\
{[2.9998]^{*}}\end{array}$ & $\begin{array}{c}3.2945 \mathrm{e}- \\
005 \\
{[3.0310]^{*}}\end{array}$ \\
\hline$G_{1}$ & $\begin{array}{c}0.76615 \\
{[21.1240]^{*}}\end{array}$ & $\begin{array}{c}0.76538 \\
{[14.0916]^{*}}\end{array}$ & $\begin{array}{c}0.76632 \\
{[2.4319]^{*}}\end{array}$ & \\
\hline$G_{2}$ & & & & $\begin{array}{c}0.54682 \\
{[4.7066]^{*}}\end{array}$ \\
\hline$A_{1}$ & $\begin{array}{c}0.18938 \\
{[4.6456]^{*}}\end{array}$ & $\begin{array}{c}0.18823 \\
{[3.1080]^{*}}\end{array}$ & $\begin{array}{c}0.18925 \\
{[3.1159]^{*}}\end{array}$ & $\begin{array}{c}0.16089 \\
{[3.0757]^{*}}\end{array}$ \\
\hline$A_{2}$ & & $\begin{array}{c}0.0017844 \\
0.0267\end{array}$ & & $\begin{array}{c}0.21993 \\
3.1189 *\end{array}$ \\
\hline AIC & -1.3358 & -1.3338 & -1.3338 & -1.3325 \\
\hline BIC & -1.3219 & -1.3165 & -1.3165 & -1.3117 \\
\hline
\end{tabular}
pada Indosat

Keterangan: tanda $[\ldots]^{*}$ menunjukkan T-Stat $>$ T-tab pada $\alpha=0,05$

dengan melihat Tabel 3.5 diketahui hasil estimasi koefisien model GARCH IHSG, dimana peramalan menggunakan model GARCH $(1,1)$ paling baik dibanding model GARCH yang lainnya. Hal ini dapat dilihat dari uji AIC dan BIC yang memberikan nilai minimum pada peramalan model GARCH $(1,1)$. Sehingga model GARCH $(1,1)$ pada Indosat adalah

$$
\begin{aligned}
\sigma_{t}^{2}=0,0017467 & +0.76615 \sigma_{t-1}^{2} \\
& +0.18938 \varepsilon_{t-1}^{2}
\end{aligned}
$$

dengan $\sigma_{t}^{2}$ adalah ramalan nilai variansi periode $t, \varepsilon_{t-1}^{2}$ adalah nilai residual periode $t-1$, dan $\sigma_{t-1}^{2}$ adalah nilai variansi periode $t-1$.

Tabel 3.6. Estimasi Parameter Model GARCH pada Unilever

\begin{tabular}{|c|c|c|c|c|}
\hline Model & $\begin{array}{c}\text { GARCH } \\
(1,1)\end{array}$ & $\begin{array}{c}\text { GARCH } \\
(1,2)\end{array}$ & $\begin{array}{c}\text { GARCH } \\
(2,1)\end{array}$ & $\begin{array}{c}\text { GARCH } \\
(2,2)\end{array}$ \\
\hline $\mathrm{K}$ & $2 \mathrm{e}-007$ & $2 \mathrm{e}-007$ \\
& {$[0.0602]$} & {$[0.0588]$} & $2 \mathrm{e}-007$ & $2 \mathrm{e}-007$ \\
{$[0.0365]$} & {$[0.0291]$} \\
\hline$G_{1}$ & 0.98736 & 0.98733 & 0.058022 & 0.060979 \\
& {$[40.2778]^{*}$} & {$[39.5789]^{*}$} & {$[0.3352]$} & {$[0.2575]$} \\
\hline$G_{2}$ & & & 0.91594 & \\
& & & {$[5.5444]^{*}$} & \\
\hline$A_{1}$ & 0.0088373 & 0.0088629 & 0.019531 & 0.019494 \\
& {$[0.8683]$} & {$[0.2168]$} & {$[1.2163]$} & {$[1.1531]$} \\
\hline$A_{2}$ & & & & \\
\hline AIC & -1.3305 & -1.3285 & -1.3293 & -1.3273 \\
\hline $\mathrm{BIC}$ & -1.3167 & -1.3112 & -1.3120 & -1.3065 \\
\hline
\end{tabular}

Keterangan: tanda $[\ldots]^{*}$ menunjukkan T-Stat $>$ T-tab pada $\alpha=0,05$

dengan melihat Tabel 3.6 diketahui hasil estimasi koefisien model GARCH IHSG, dimana peramalan menggunakan model GARCH $(1,1)$ paling baik dibanding model GARCH yang lainnya. Hal ini dapat dilihat dari uji AIC dan BIC yang memberikan nilai minimum pada peramalan model GARCH $(1,1)$. Sehingga model GARCH $(1,1)$ pada Unilever adalah

$$
\begin{gathered}
\sigma_{t}^{2}=0,0000002+0.98736 \sigma_{t-1}^{2}+ \\
0.0088373 \varepsilon_{t-1}^{2}
\end{gathered}
$$

dengan $\sigma_{t}^{2}$ adalah ramalan nilai variansi periode $t, \varepsilon_{t-1}^{2}$ adalah nilai residual periode $t-1$, dan $\sigma_{t-1}^{2}$ adalah nilai variansi periode $t-1$.

Tabel 3.7. Estimasi Parameter Model GARCH pada Telkom

\begin{tabular}{|c|c|c|c|c|}
\hline Model & $\begin{array}{c}\text { GARCH } \\
(1,1)\end{array}$ & $\begin{array}{c}\text { GARCH } \\
(1,2)\end{array}$ & $\begin{array}{c}\text { GARCH } \\
(2,1)\end{array}$ & $\begin{array}{c}\text { GARCH } \\
(2,2)\end{array}$ \\
\hline $\mathrm{K}$ & $\begin{array}{c}5.5684 \mathrm{e}- \\
005 \\
{[1.4115]}\end{array}$ & $\begin{array}{c}0.0001346 \\
{[2.4351]^{*}}\end{array}$ & $\begin{array}{c}5.5735 \mathrm{e}- \\
005 \\
{[1.1287]}\end{array}$ & $\begin{array}{c}0.00015687 \\
{[2.1471]^{*}}\end{array}$ \\
\hline$G_{1}$ & 0.70715 & 0.28013 & 0.70696 & \\
& {$[3.9479]^{*}$} & {$[1.1288]$} & {$[0.9094]$} & \\
\hline$G_{2}$ & & & & 0.16534 \\
& & & $0.7245]$ \\
\hline$A_{1}$ & 0.091605 & 0.057514 & 0.091648 & 0.066124 \\
& {$[1.8646]^{*}$} & {$[0.9304]$} & {$[1.0747]$} & {$[1.1147]$} \\
\hline$A_{2}$ & & 0.19186 & & 0.21945 \\
& & {$[2.5018]^{*}$} & & {$[2.8288]^{*}$} \\
\hline AIC & -1.2848 & -1.2869 & -1.2828 & -1.2857 \\
\hline BIC & -1.2710 & -1.2696 & -1.2655 & -1.2649 \\
\hline
\end{tabular}

Keterangan: tanda $[\ldots]^{*}$ menunjukkan T-Stat $>$ T-tab pada $\alpha=0,05$ 
Berdasarkan Tabel 3.7 diketahui hasil estimasi koefisien model GARCH Telkom, dimana peramalan menggunakan model GARCH $(1,1)$ paling baik dibanding model GARCH yang lainnya. Hal ini dapat dilihat dari uji AIC dan BIC yang memberikan nilai minimum pada peramalan model GARCH $(1,1)$. Sehingga model GARCH $(1,1)$ pada Telkom adalah

$$
\begin{gathered}
\sigma_{t}^{2}=0,0055684+0.70715 \sigma_{t-1}^{2}+ \\
0.091605 \varepsilon_{t-1}^{2}
\end{gathered}
$$

dengan $\sigma_{t}^{2}$ adalah ramalan nilai variansi periode $t, \varepsilon_{t-1}^{2}$ adalah nilai residual periode $t-1$, dan $\sigma_{t-1}^{2}$ adalah nilai variansi periode $t-1$.

Tahap selanjutnya dalam peramalan menggunakan model GARCH setelah dilakukan estimasi dan diperoleh model terbaik adalah melakukan uji Ljung-Box terhadap residual kuadrat yang distandarisasi $\left(z_{t}\right)$ dan uji ARCH terhadap residual yang distandarisasi $\left(z_{t}\right)$ dari model yang diperoleh.

Tabel 3.8 Uji Ljung-Box Residual IHSG Setelah

\begin{tabular}{|c|c|c|c|c|c|}
\hline \multicolumn{6}{|c|}{ Saham IHSG } \\
\hline \multicolumn{3}{|c|}{ Uji Ljung Box } & \multicolumn{3}{|c|}{ Uji ARCH LM } \\
\hline $\mathbf{p}$ & Qstat & CV & $\mathbf{p}$ & Qstat & CV \\
\hline 0.6403 & 0.2184 & 3.8415 & 0.5686 & 0.3250 & 3.8415 \\
\hline 0.4525 & 4.7082 & 11.0705 & 0.7462 & 2.6992 & 11.0705 \\
\hline 0.7405 & 5.9942 & 16.9190 & 0.9209 & 3.8514 & 16.9190 \\
\hline 0.7448 & 9.3659 & 22.3620 & 0.9689 & 5.2649 & 22.3620 \\
\hline 0.7453 & 12.8633 & 27.5871 & 0.9829 & 7.0463 & 27.5871 \\
\hline 0.5220 & 19.9888 & 32.6706 & 0.4331 & 21.4276 & 32.6706 \\
\hline \multicolumn{6}{|c|}{ Holcim } \\
\hline \multicolumn{3}{|c|}{ Qstat } & \multicolumn{3}{|c|}{ Qstat } \\
\hline 0.4028 & 0.6998 & 3.8415 & 0.3571 & 0.8481 & 3.8415 \\
\hline 0.7425 & 2.7238 & 11.0705 & 0.8591 & 1.9271 & 11.0705 \\
\hline 0.2749 & 11.0116 & 16.9190 & 0.4521 & 8.8409 & 16.9190 \\
\hline 0.4845 & 12.5334 & 22.3620 & 0.6879 & 10.0742 & 22.3620 \\
\hline 0.2785 & 19.9177 & 27.5871 & 0.7698 & 12.4877 & 27.5871 \\
\hline 0.3430 & 23.0190 & 32.6706 & 0.9047 & 13.1105 & 32.6706 \\
\hline \multicolumn{6}{|c|}{ Indofood } \\
\hline $\mathbf{p}$ & Qstat & $\mathrm{CV}$ & $\mathbf{p}$ & Qstat & $\mathrm{CV}$ \\
\hline 0.9654 & 0.0019 & 3.8415 & 0.8629 & 0.0298 & 3.8415 \\
\hline 0.7755 & 2.5064 & 11.0705 & 0.9973 & 0.3167 & 11.0705 \\
\hline 0.7646 & 5.7505 & 16.9190 & 1.0000 & 0.4884 & 16.9190 \\
\hline 0.9198 & 6.6379 & 22.3620 & 1.0000 & 0.6235 & 22.3620 \\
\hline 0.9796 & 7.2788 & 27.5871 & 1.0000 & 0.6771 & 27.5871 \\
\hline 0.9914 & 8.6974 & 32.6706 & 1.0000 & 0.8404 & 32.6706 \\
\hline \multicolumn{6}{|c|}{ Indosat } \\
\hline $\mathbf{p}$ & Qstat & $\mathrm{CV}$ & $\mathbf{p}$ & Qstat & CV \\
\hline 0.9453 & 0.0047 & 3.8415 & 0.8651 & 0.0289 & 3.8415 \\
\hline 0.8803 & 1.7677 & 11.0705 & 0.9978 & 0.2909 & 11.0705 \\
\hline 0.9007 & 4.1586 & 16.9190 & 0.9999 & 0.5631 & 16.9190 \\
\hline 0.9649 & 5.4156 & 22.3620 & 1.0000 & 0.8041 & 22.3620 \\
\hline 0.9755 & 7.5368 & 27.5871 & 1.0000 & 1.0305 & 27.5871 \\
\hline 0.9938 & 8.2950 & 32.6706 & 1.0000 & 1.3315 & 32.6706 \\
\hline
\end{tabular}
Estimasi

\begin{tabular}{|ccc|ccc|}
\hline \multicolumn{7}{|c|}{ Unilever } \\
\hline $\mathbf{p}$ & Qstat & $\mathbf{C V}$ & $\mathbf{p}$ & Qstat & $\mathbf{C V}$ \\
0.4731 & 0.5146 & 3.8415 & 0.9920 & 0.0001 & 3.8415 \\
0.9380 & 1.2703 & 11.0705 & 0.8499 & 1.9946 & 11.0705 \\
0.9824 & 2.4434 & 16.9190 & 0.9793 & 2.5583 & 16.9190 \\
0.9953 & 3.5152 & 22.3620 & 0.9975 & 3.1171 & 22.3620 \\
0.9945 & 5.7876 & 27.5871 & 0.9997 & 3.6389 & 27.5871 \\
0.9934 & 8.3720 & 32.6706 & 0.9994 & 6.0715 & 32.6706 \\
\hline \multicolumn{7}{|c|}{ Telkom } \\
\hline $\mathbf{p}$ & Qstat & $\mathbf{C V}$ & $\mathbf{p}$ & Qstat & $\mathbf{C V}$ \\
0.5588 & 0.3418 & 3.8415 & 0.6534 & 0.2016 & 3.8415 \\
0.4850 & 4.4616 & 11.0705 & 0.2047 & 7.2209 & 11.0705 \\
0.4820 & 8.5278 & 16.9190 & 0.2216 & 11.8544 & 16.9190 \\
0.6921 & 10.0229 & 22.3620 & 0.4975 & 12.3711 & 22.3620 \\
0.6575 & 14.1348 & 27.5871 & 0.7093 & 13.3963 & 27.5871 \\
0.7435 & 16.4557 & 32.6706 & 0.8305 & 14.8476 & 32.6706 \\
\hline
\end{tabular}

dengan melihat Tabel 3.8 dapat dilihat bahwa berdasarkan Uji Ljung-box residual kuadrat yang distandarisasi $\left(z_{t}\right)$ dan uji ARCH LM terhadap nilai dugaan residual kuadratnya diperoleh bahwa nilai Q lebih kecil dari Critical Value (CV) atau nilai $\mathrm{P}$ lebih besar dari $a=0,05$ yang mengindikasikan tolak $H_{0}$ atau terima $H_{1}$ yang artinya nilai dugaan residual kuadrat IHSG sudah tidak berautokorelasi atau stasioner dan sudah tidak terdapat efek ARCHGARCH dalam residual.

\section{Perhitungan Nilai Beta Saham Unggulan}

Tabel 3.9. Nilai beta pasar dari saham unggulan.

\begin{tabular}{|c|c|c|}
\hline Nama Saham & $\begin{array}{c}\text { Nilai Beta } \\
\text { Saham }\end{array}$ & Variansi \\
\hline IHSG & 0.0092 & $8.3931 \mathrm{e}-005$ \\
\hline HOLCIM & 0.0208 & $4.3457 \mathrm{e}-004$ \\
\hline INDOFOOD & 0.0133 & $1.7749 \mathrm{e}-004$ \\
\hline INDOSAT & 0.0161 & $2.5803 \mathrm{e}-004$ \\
\hline UNILEVER & 0.0153 & $2.3389 \mathrm{e}-004$ \\
\hline TELKOM & 0.0169 & $2.8402 \mathrm{e}-004$ \\
\hline
\end{tabular}

Berdasarkan Tabel 3.9 terlihat bahwa perhitungan beta pasar berada dalam kelompok $\beta<1$ dimana saham unggulan memiliki risiko lebih rendah dari risiko pasar. Nilai beta tertinggi dimiliki oleh saham HOLCIM dengan $\beta=0.0208$ dengan risiko saham sebesar 4.3457e-004. Hal ini sesuai dengan asumsi bahwa semakin besar nilai beta suatu saham maka semakin tinggi tingkat risiko saham tersebut dan semakin besar pula pengembalian yang diberikan saham tersebut. 
Tabel 3.10. Nilai Beta Pasar dari Saham Unggulan Menggunakan Model GARCH.

\begin{tabular}{|c|c|c|}
\hline Nama Saham & $\begin{array}{c}\text { Nilai Beta } \\
\text { Saham }\end{array}$ & Variansi \\
\hline HOLCIM & 0.3107 & 0.0965 \\
\hline INDOFOOD & 0.1808 & 0.0327 \\
\hline INDOSAT & 0.2881 & 0.0830 \\
\hline UNILEVER & 0.1041 & 0.0108 \\
\hline TELKOM & 0.2086 & 0.0435 \\
\hline
\end{tabular}

Berdasarkan Tabel 3.10 terlihat bahwa perhitungan beta pasar berada dalam kelompok $\beta<1$ dimana saham unggulan memiliki risiko lebih rendah dari risiko pasar. Nilai beta tertinggi dimiliki oleh saham HOLCIM dengan $\beta=0.3107$ dengan risiko saham yang ditanggung sebesar 0.0965. Hal ini sesuai dengan asumsi bahwa semakin besar nilai betasuatu saham maka semakin tinggi tingkat risiko saham tersebut dan semakin besar pula pengembalian yang diberikan saham tersebut.

\section{Perbandingan Nilai Beta Saham Unggulan}

\begin{tabular}{|c|c|c|}
\hline \multicolumn{3}{|c|}{ Beta Pasar Saham Unggulan } \\
\hline Nama Saham & Nilai Beta & Variansi \\
\hline HOLCIM & 0.0208 & $4.3457 \mathrm{e}-004$ \\
\hline INDOFOOD & 0.0133 & $1.7749 \mathrm{e}-004$ \\
\hline INDOSAT & 0.0161 & $2.5803 \mathrm{e}-004$ \\
\hline UNILEVER & 0.0153 & $2.3389 \mathrm{e}-004$ \\
\hline TELKOM & 0.0169 & $2.8402 \mathrm{e}-004$ \\
\hline
\end{tabular}

\begin{tabular}{|c|c|c|}
\hline \multicolumn{3}{|c|}{ Beta Pasar Saham Model GARCH } \\
\hline Nama Saham & Nilai Beta & Variansi \\
\hline HOLCIM & 0.3107 & 0.0965 \\
\hline INDOFOOD & 0.1808 & 0.0327 \\
\hline INDOSAT & 0.2881 & 0.0830 \\
\hline UNILEVER & 0.1041 & 0.0108 \\
\hline TELKOM & 0.2086 & 0.0435 \\
\hline
\end{tabular}

Pada tabel di atas terlihat bahwa nilai beta menggunakan model GARCH lebih besar dibandingkan beta pasar saham unggulan. Semakin besar nilai beta yang diperoleh maka saham tersebut semakin baik digunakan dalam berinvestasi. Selain beta nilai variansi atau risiko juga sangat penting dalam melakukan investasi saham. Terlihat bahwa variansi model GARCH lebih besar dibandingkan beta pasar saham unggulan. Semakin besar risiko yang dihadapi oleh investor maka semakin besar keuntungan yang diperoleh.

\section{KESIMPULAN DAN SARAN}

Berdasarkan uraian dan analisisnya, dapat diambil kesimpulan saham-saham unggulan pada periode 23 September 2013 sampai 24 September 2014 memperoleh $\beta<1$ dimana saham unggulan memiliki risiko lebih rendah dari risiko pasar. Dan berdasarkan perhitungan beta pasar saham unggulan dan diperoleh nilai beta menggunakan model GARCH lebih besar dibandingkan dibandingkan nilai beta pasar.

Dari penelitian di atas maka saran yang dapat penulis berikan adalah untuk investor yang berminat untuk melakukan investasi dengan menanam modalnya di bursa saham namun bukan bertujuan untuk spekulasi semata, sangat penting untuk melakukan analisa terhadap kinerja saham tersebut terlebih dahulu sehingga dapat mengetahui tingkat risiko dan tingkat pengembalian dari masing-masing saham dan untuk penelitian selanjutnya selain model GARCH dapat digunakan metode lain dalam pehitungan beta saham seperti metode CAPM dan juga lebih banyak lagi jenis saham yang dibandingkan nilai $\beta$, misalnya indeks sektoral atau indeks LQ45.

\section{DAFTAR PUSTAKA}

[1] Agus Sartono. 1999. Manajemen Keuangan.edisi 3. BPFE UGM.

[2] Ang, R. 1997. Pasar Modal Indonesia. Media SoftIndonesia. Jakarta.

[3] Bollerslev, T.et all. 1986. Glosary to ARCH (GARCH). Volatility and Time Series 8,137-164.

[4] Francis, Jack Clark. Wiley Finance, Volume 795. Modern Portofolio Theory+WS. Foundations, Analysis, and New Developments. Wiley, p. 311.

[5] Husnan, Suad. 1998. Dasar-dasar Teori Portofolio. UPP AMP YKPM. Yogyakarta.

[6] Hwang. SY., Basawa, I.V. Stationarity and Moment Structure for Box Coxtransformed Threshold GARCH(1,1) Processes. Journal Statistics and Probability Letters, 68 (20040, 209) A, S220.

[7] Jogiyanto, Hartono 1998. Teori Portofolio dan Analisis Sekuritas.edisi ketiga. BPFE. Yogyakarta. 
[8] Jogiyanto, Hartono 2000. Teori Portofolio dan Analisis Investasi. edisi keempat. BPFE. Yogyakarta.

[9] Luenberger, D.G. 1998. Investment Science.Oxford University Press. New York.

[10] Riyanto, B. 1999. Dasar-dasar Pembelanjaan Perusahaan. BPFE. Yogyakarta.

[11] Sawidji, Widoatmojo. 1996. Cara Sehat Investasi di Pasar Modal. Jakarta: Jurnalindo Aksan Grafika.

[12] Weston, J. Fred dan Thomas E. Copeland. 1995. Manajeman Keuangan Jilid I, Edisi Keempat, Bina AksaraJakarta. 